\section{Research renewal at the Canadian Thoracic Society}

A s the President of the Canadian Thoracic Society (CTS), I subscribe to the view that the CTS can only be as strong as its three pillars: guidelines, education and research. During the past few years, we have been working diligently in the field of guidelines and education. This is most evident in the creation of the Canadian Respiratory Guidelines Committee (CRGC) and the Canadian Respiratory Conference, as well as in the continued successes of the annual CTS Scientific Program at CHEST. The CTS has also been consolidating its educational policies and procedures as part of the renewal of our status as an accredited continuing medical education provider. We have been industrious in guidelines development and education, and will continue on that path. Now, however, it is time to turn our attention to the third pillar: research.

For some time now, the CTS Executive and Research Committee have been exploring a number of issues relating to research. As we did so, it became increasingly clear that it was time to take stock of our research activities, and to take a step back and examine our research program, as well as the state of respiratory research in Canada as a whole. It was time to look at where we are today and set a vision for the future.

To that end, the CTS Executive and Research Committee recently took action. On June 19, we invited a small group of CTS leaders and members with research expertise to a meeting in Winnipeg, Manitoba. The June meeting is a precursor to a second meeting in the fall that will bring together a larger group of stakeholders in view of developing a national research agenda. At the June meeting, we addressed a number of issues.

Collaboration within the national respiratory research community

As we move forward in our efforts to develop a national research agenda, it is vital that we reduce duplication and foster collaboration throughout the national respiratory research community. As a starting point, we need to identify all stakeholders. We will, therefore, seek to partner with the National Lung Health Framework to develop a national database of investigators that would identify not only the researchers, but the nature of their research activities as well. The Framework's knowledge portal would be an ideal home for this database.

We will also promote the development of partnerships between basic scientists and clinicians, and facilitate connections between researchers, clinicians, networks and research chairs. We will work closely with the Canadian Respiratory Clinical Research Consortium (CRCRC) to reach these goals.

Funding and advocacy

Currently, federal funding allocated to respiratory research does not adequately reflect the burden of respiratory illness care.

\section{Un nouveau souffle pour la recherche à la Société canadienne de thoracologie}

A titre de président de la Société canadienne de thoracologie (SCT), j'adhère au principe selon lequel la SCT sera aussi forte que les trois piliers qui la supportent, soit les lignes directrices, la formation et la recherche. Depuis quelques années, je me suis beaucoup concentré sur les lignes directrices et la formation et cela se reflète particulièrement dans la mise sur pied du Comité pour les Lignes directrices canadiennes en pneumologie et la Conférence canadienne de pneumologie, de même que dans les réussites que continue d'enregistrer le Programme scientifique de la SCT en marge de l'événement CHEST. La SCT a également consolidé ses politiques et son fonctionnement au chapitre de la formation en assurant le maintien de son statut de fournisseur accrédité de formation médicale continue. Nous avons élaboré des directives et des programmes de formation et nous continuerons de le faire. Maintenant, toutefois, il est temps d'accorder plus d'attention au troisième pilier : la recherche.

Depuis un certain temps, l'exécutif et le Comité de recherche de la SCT exploraient un certain nombre d'avenues ayant trait à la recherche. Ce faisant, nous nous sommes rendu compte que le temps est venu de dresser un bilan de nos activités de recherche, de prendre du recul par rapport à notre programme et de faire le point sur la recherche en pneumologie au Canada dans son ensemble. En somme, il s'agit à présent d'examiner la situation actuelle et d'établir notre vision pour l'avenir.

À cette fin, l'exécutif et le Comité de recherche de la SCT ont récemment pris des mesures. Le 19 juin, nous avons invité un petit groupe de dirigeants et de membres de la SCT ayant une expertise en recherche à participer à une réunion, à Winnipeg, au Manitoba. La rencontre de juin pavait la voie à une seconde réunion qui aura lieu cet automne et regroupera un plus grand nombre d'intervenants dans le but de développer un programme national de recherche. Lors de la rencontre de juin, nous avons abordé plusieurs questions.

Collaboration de la communauté vouée à la recherche en pneumologie à l'échelle nationale

À mesure que la mise au point de notre programme national de recherche avancera, nous nous emploierons à réduire le double emploi et à promouvoir la collaboration entre tous les intervenants de la recherche en pneumologie au pays. Comme point de départ, nous devons identifier toutes les parties prenantes. Nous chercherons donc à établir des partenariats avec le Cadre de travail national sur la santé pulmonaire pour établir une base de données nationale des chercheurs, qui permettrait non seulement de dresser la liste des scientifiques, mais également de connaître la nature de leurs activités de recherche. Idéalement, c'est le Portail du savoir du Cadre de travail 
There is a clear need for us to step up our advocacy efforts to redress this imbalance and secure additional funding for respiratory research in Canada. We will strive to be creative in our fundraising efforts and use any useful models, such as fund matching or bridge funding, and will work closely with our partners to make progress in this vital area.

\section{Clinical versus basic research}

Data regarding respiratory research has revealed an imbalance between funding allocated to clinical research and basic research, with basic research receiving a much larger portion of available funding. A low level of funding for clinical research puts Canada at risk of losing clinical researchers - particularly young investigators - to other nations.

The CTS will, therefore, take action with a two-pronged approach: it will seek to increase the number of clinical research proposals and will also advocate for an adjustment in funding streams to ensure clinical research receives sufficient funding.

The CTS is committed to working with its partners, such as the Canadian Institutes of Health Research, to ensure adequate funding is available for both basic and clinical research.

\section{Governance and integration}

The CTS is currently undergoing a governance review process. As part of the process, it will be vital that research is well integrated into the overall CTS structure and given its due consideration. Research could be further integrated through our national conference - the Canadian Respiratory Conference - an ideal venue for bringing clinicians and researchers together. Furthermore, reporting mechanisms should be in place to ensure that the CTS Executive and Board of Directors, as well The Lung Association Board of Directors, are well informed about research activities and issues, and are positioned to act decisively in those areas.

In addition to addressing the issues outlined above, the June meeting resulted in concrete plans for moving forward:

An Interim Research Steering Committee was formed to shepherd the research renewal process. Shawn Aaron (CRCRC) and Andrew Halayko (CTS Research Committee) agreed to co-chair the Steering Committee for the next six months. Both the CRCRC and the CTS Research Committee will contribute an additional two members to the committee, and the CTS President and the Chair of the Canadian Respiratory Health Professionals Research Committee will serve as ex officio members.

The interim Steering Committee will be responsible for identifying key priority areas for the CTS research program and for planning the national research meeting in November, to which a broader range of key stakeholders will be invited. The national meeting will combine a planning meeting as well as a scientific symposia component. The anticipated outcome of this renewal process is the development of a national respiratory research agenda.

On behalf of the CTS Executive, I thank Drs Aaron and Halayko for taking on the leadership of the research renewal process, as well as Irvin Mayers, the current Chair of the CTS Research Committee. Many thanks as well to the other participants who contributed to the June meeting: Yves Berthiaume, Larry Lands, Rob McFadden, Redwan Moqbel, Denis O’Donnell national sur la santé pulmonaire qui hébergerait cette base de données.

Nous ferons également la promotion des partenariats entre les spécialistes de la recherche fondamentale et les cliniciens et nous faciliterons les rapports entre les chercheurs, les cliniciens, les réseaux et les directeurs de recherche. Nous travaillerons étroitement avec le Consortium canadien de recherche clinique en pneumologie (CCRCP) pour atteindre ces objectifs.

\section{Financement et défense des intérêts}

À l'heure actuelle, le financement fédéral accordé à la recherche en pneumologie n'est pas proportionnel au fardeau que représentent les soins en santé respiratoire. Il faut sans contredit exercer plus de pression pour corriger ce déséquilibre et assurer un meilleur financement de la recherche en pneumologie au Canada. Nous tenterons de faire preuve de créativité dans nos activités à cet égard et nous utiliserons tous les modèles utiles, par exemple, subventions paritaires ou financements temporaires, et nous travaillerons étroitement avec nos partenaires pour réaliser des progrès dans ce domaine vital.

\section{Recherche clinique versus fondamentale}

Les données sur la recherche en pneumologie ont révélé un écart entre le financement de la recherche clinique et celui de la recherche fondamentale, cette dernière recevant une part beaucoup plus imposante des fonds alloués. Si le Canada finance trop peu la recherche clinique, il risque de perdre ses chercheurs, et tout particulièrement les plus jeunes d'entre eux, susceptibles d'être séduits par les invitations qui leur sont faites pour aller travailler dans d'autres pays.

La SCT adoptera donc une double mesure d'intervention : elle cherchera à accroître le nombre de projets d'études cliniques et fera également pression pour obtenir une harmonisation de ses sources de financement, afin que la recherche clinique reçoive des fonds suffisants.

La SCT s'engage à travailler avec ses partenaires, comme les Instituts de recherche en santé du Canada, pour que des sommes suffisantes soient allouées à la recherche clinique et à la recherche fondamentale.

\section{Gouvernance et intégration}

La SCT procède actuellement à une révision de sa gouvernance. Dans le cadre de ce processus, elle verra à ce que la recherche soit bien intégrée à sa structure globale et qu'elle reçoive toute l'attention voulue. La recherche pourrait idéalement trouver la voie d'une meilleure intégration par le biais de notre conférence nationale, la Conférence canadienne de pneumologie, qui est une occasion idéale de réunir les cliniciens et les chercheurs. En outre, des mécanismes seront mis en place pour la production de rapports à l'intention de l'exécutif et du conseil d'administration de la SCT, de même qu'à l'intention du conseil d'administration de l'Association pulmonaire, afin que tous soient tenus bien informés des activités et des questions ayant trait à la recherche et soient en mesure d'adopter des mesures décisives pour agir dans ce domaine.

En plus de s'attaquer aux questions présentées ci-dessus, la réunion de juin a abouti à différents plans concrets :

Un Comité intérimaire de direction de la recherche a été formé pour coordonner la relance de la recherche. Shawn Aaron (CCRCP) et Andrew Halayko (Comité de recherche de la SCT) ont accepté de coprésider le Comité de direction 
and Teresa To. I also extend my appreciation to Janet Sutherland, CTS Director, Anne Van Dam, Research Director, and Michelle McEvoy, Research Manager, for their invaluable support.

I am very excited about these developments! I am quite certain that the Steering Committee will succeed in helping us strengthen CTS research programs and develop a robust national research agenda in collaboration with partners and stakeholders from across the country.

A strong research pillar will mean a stronger, more vibrant and successful CTS, which is good news for respiratory health in Canada.

Respectfully submitted,

Michel Rouleau MD President, Canadian Thoracic Society pour les six prochains mois. Le CCRCP et le Comité de recherche de la SCT délégueront deux autres membres auprès du Comité et les présidents de la SCT et du Comité canadien de recherche en santé respiratoire agiront à titre de membres de plein droit.

Le Comité intérimaire de direction sera chargé d'identifier les principaux domaines à inscrire au programme de recherche de la SCT et de planifier la rencontre nationale sur la recherche qui se tiendra en novembre, et à laquelle un éventail plus large d'intervenants seront conviés. La réunion nationale servira à la fois de rencontre de planification et d'avenue pour la présentation de symposiums scientifiques. Si tout se déroule normalement, ce processus de relance devrait aboutir à la mise sur pied d'un programme de recherche national en pneumologie.

Au nom de l'exécutif de la SCT, je remercie les docteurs Aaron et Halayko d'avoir pris les rênes de cette opération visant à donner un nouveau souffle à la recherche, de même qu'Irvin Mayers, le président actuel du Comité de recherche de la SCT. Grand merci également à d'autres participants qui ont assisté à la réunion de juin : Yves Berthiaume, Larry Lands, Rob McFadden, Redwan Moqbel, Denis O’Donnell et Teresa To. Je tiens également à exprimer ma gratitude envers Janet Sutherland, directrice de la SCT, Anne Van Dam, directrice de la recherche, et Michelle McEvoy, chef de la recherche, pour leur inestimable appui.

Ces projets sont des plus intéressants! Je suis certain que le Comité de direction réussira à nous aider à consolider les programmes de recherche de la SCT et à mettre au point un programme scientifique national solide, en collaboration avec nos partenaires et autres intervenants des quatre coins du pays.

En consolidant son pilier recherche, la SCT deviendra plus forte et plus dynamique, elle remportera plus de succès, ce qui ne peut être que de bon augure pour la santé respiratoire au Canada.

Salutations distinguées,

Michel Rouleau, M.D.

Président, Société canadienne de thoracologie 


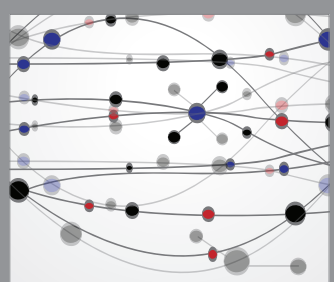

The Scientific World Journal
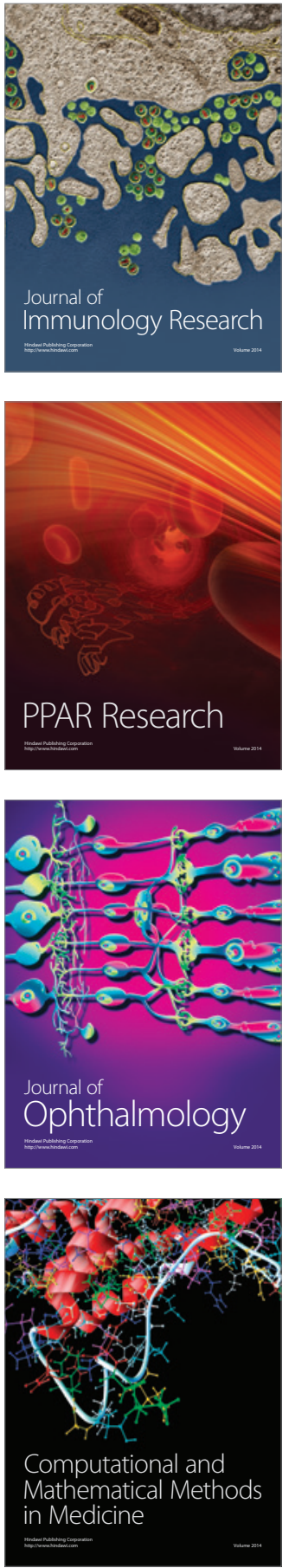

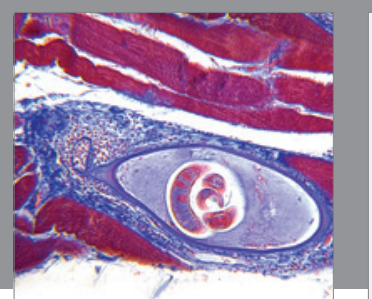

Gastroenterology Research and Practice

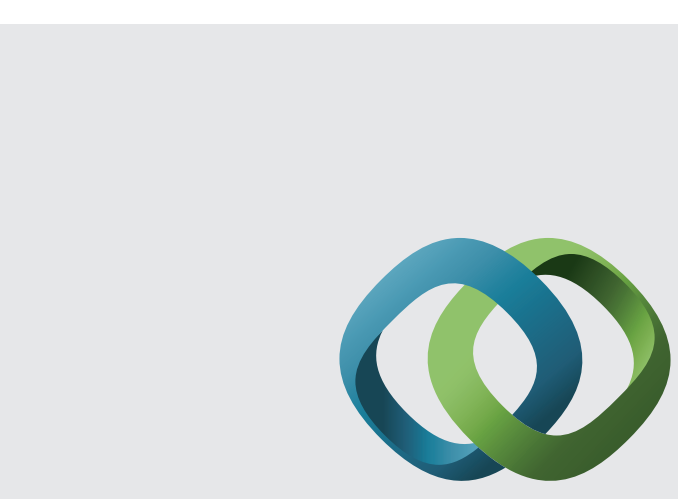

\section{Hindawi}

Submit your manuscripts at

http://www.hindawi.com
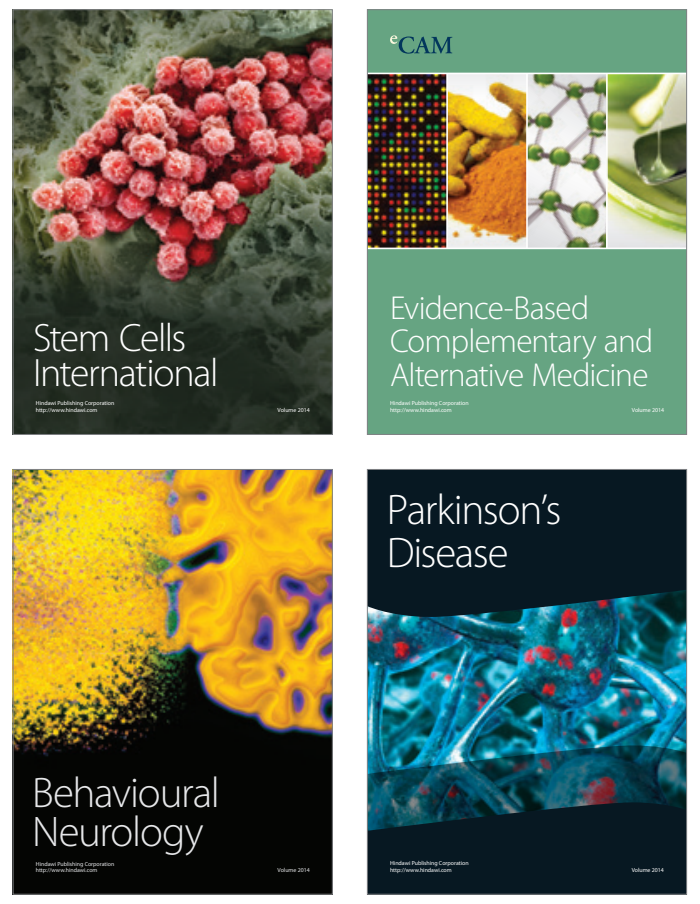
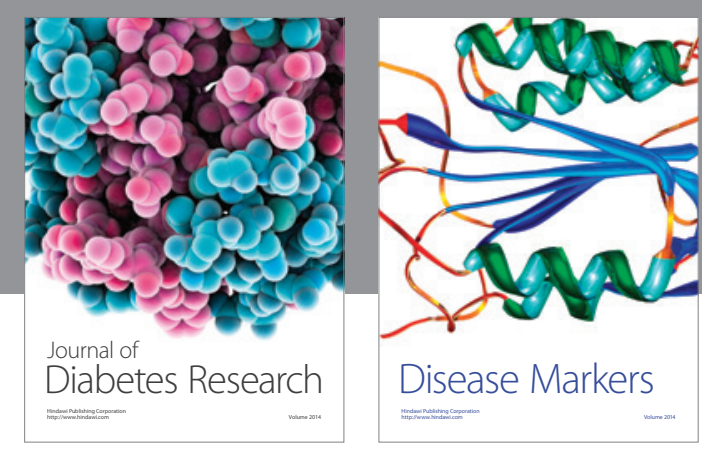

Disease Markers
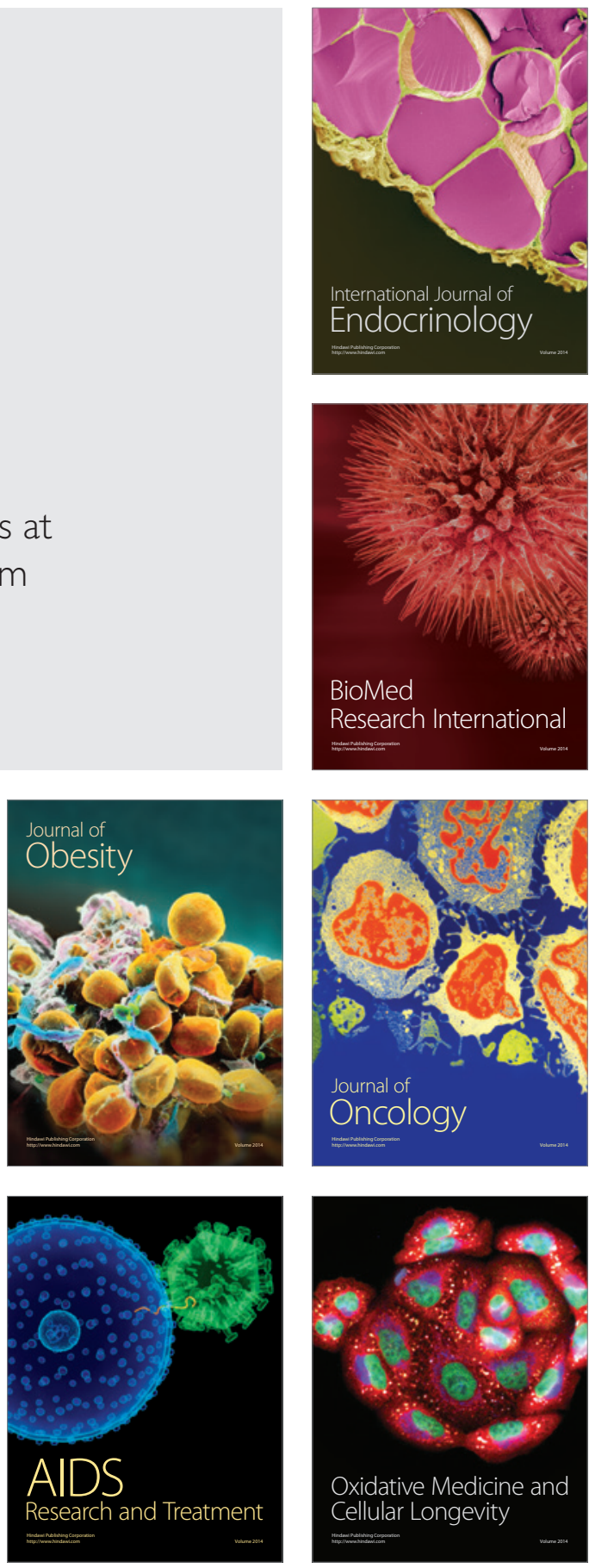